\title{
Nutritional and environmental studies on an ocean-going oil tanker. 4. The diet of seamen
}

\author{
T. P. EDDY, ERICA F. WHEELER, and ANNE L. STOCK \\ Department of Human Nutrition, London School of Hygiene and Tropical Medicine, Keppel \\ Street, London W.C.1, and Department of Nutrition, Queen Elizabeth College, London W.8
}

Eddy, T. P., Wheeler, Erica F., and Stock, Anne L. (1971). Brit. J. industr. Med., 28, 342-352. Nutritional and environmental studies on an ocean-going oil tanker. 4. The diet of seamen. Previous reports by Collins and his colleagues (1971a, b) and Eddy, Stock, and Wheeler (1971) have described energy and nutrient balances measured during a voyage of the oil tanker S.S. Esso Newcastle to the Persian Gulf in July and August 1967. This study of the diet of seamen during the voyage describes inter-relationships of the energy-yielding constituents of the diet, particularly the relationship of alcohol to other constituents, and vitamin intakes.

For the whole ship's crew the percentages of energy derived from the main constituents were from protein $12 \%$, fat $35 \%$, carbohydrate $40 \%$, and alcohol $13 \%$.

The intakes of six subjects studied in detail showed relatively little variation in protein, $13.9 \pm 0.4$ Joules $\%$; but greater variation in fat $(33.0 \pm 1.6 \%)$, carbohydrate $(42.7 \pm$ $1.4 \%)$, and alcohol $(10.4 \pm 1 \cdot 3 \%)$. There were high negative correlations, $r=-0.75$, between energy percentages derived from alcohol and those derived from protein and fat respectively.

Flour purchased for the ship in a foreign port was deficient in thiamine and niacin. There was a negative correlation between energy and thiamine intake, and with unfortified white flour thiamine intake would fall below the recommended allowance at intakes above 14.5 MJ $(3500 \mathrm{kcal})$. The unwitting substitution of unfortified flours in place of fortified British flour is a potential cause of deficiency.

The estimated intake of riboflavine decreased when fresh milk supplies were exhausted following the 10th day out, and would have fallen below the recommended intake of $0.5 \mathrm{mg} /$ $1000 \mathrm{kcal}(4 \cdot 186 \mathrm{MJ})$ but for the consumption of beer.

The intake of ascorbic acid was not affected by the duration of the voyage. It averaged $70 \mathrm{mg} / \mathrm{man} /$ day and was derived chiefly from citrus fruits and potatoes.

The Statutory Scale of Provisions issued under the Merchant Shipping Act. 1906, is out of date and a new scale should be drawn up.

Collins et al. (1971a, b) and Eddy, Stock, and Wheeler (1971) described nutrient and energy balances and environmental conditions on a voyage to the Persian Gulf. This paper is concerned with more general aspects of the ship's diet on the same voyage.

In a well-found modern ship with ample chilled and frozen storage and a well-equipped galley and food preparation rooms, catering standards can match those of the best establishments on shore. This was certainly true of S.S. Esso Newcastle; an ample variety of food was served throughout the voyage. The same meals were taken by officers and crew and there were no dietary distinctions on grounds of rank. Catering was equal to that found in a good class of passenger ship or a good hotel.

The quality of food carried by British merchant ships is governed by the Merchant Shipping Acts 
which make provisions for the inspection of ship's provisions and lay down a scale of provisions for the crews of British ships (Department of Trade and Industry, 1965), and by the food laws and regulations in force at the port where the ship is victualled. A ship victualling at an English port would purchase food which complied with the Food and Drugs Act, and with Regulations and Statutory Instruments made under that Act, but a British ship victualling at a foreign port might obtain food which did not comply with the requirements of British law. Flour and any foods made from flour and sold in the United Kingdom must, in accordance with statutory requirements, attain minimum specifications for certain minerals and vitamins; similarly, British margarine is fortified with vitamins $A$ and $D$, but there is no guarantee that foods obtained in foreign ports would necessarily comply with these regulations. There are provisions for the inspection of surplus food on board ship by the Inspector of Ship's Provisions but the standard laid down for inspection makes no mention of the vitamin content of margarine and says of flour that the protein content must not be lower than $10.5 \%$ and that it may be fortified with the additives required by the current "The Bread and Flour Regulations"'. The governments of some other countries, like France, not only do not fortify staple foods in the way that has become customary in Britain, but positively disapprove of such procedures and maintain satisfactory nutrition in respect of vitamins and minerals for their populations by other means.

\section{Methods}

The methods used on the voyage have been described in the previous papers of this series. Average intakes of energy and nutrients taken by the whole ship on eight days were supplemented by detailed dietary measurements on three crew members and three medical students who were the subjects of metabolic studies.

\section{Results}

The consumption of 15 different groups of foods per man per day with mean intakes of energy and nutrients are shown in Table 1 where they are

TABLE 1

Food Intake in the Esso Newcastle compared with Scales of Provisions and Rations in Previous CENTURIES

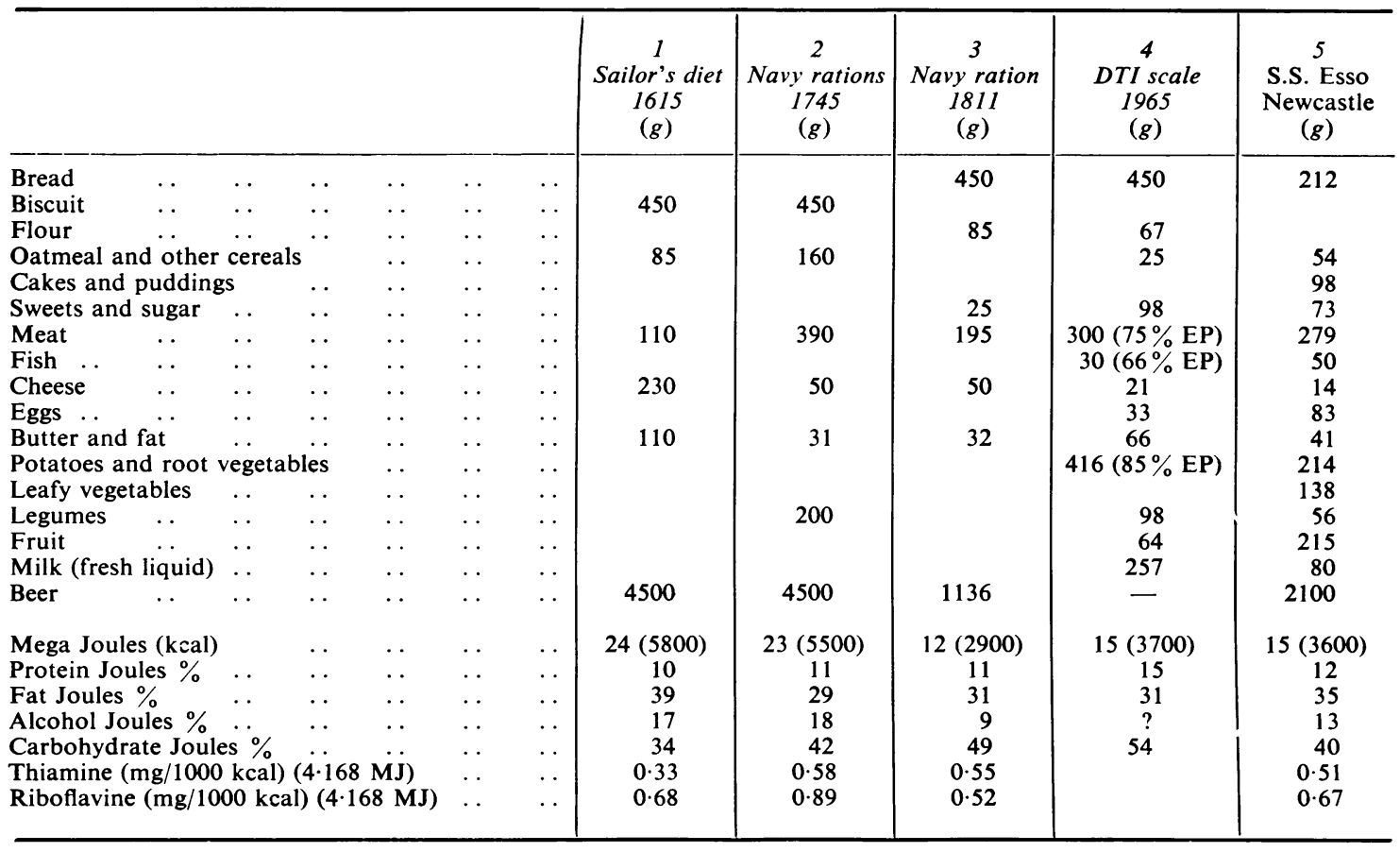

Columns 1, 2, and 3 are from Drummond and Wilbraham (1958). Column 4 is from Department of Trade \& Industry (1965). Consumption of alcohol in the Esso Newcastle is given as the equivalent in beer. Of the total energy intake of alcohol,78\% was derived from beer, $17 \%$ from wine, and $5 \%$ from spirits. EP in column 4 shows the correction made for edible portion. 
compared with three examples of ship's provisions in previous centuries, cited by Drummond and Wilbraham (1958), and with a diet made up from the current statutory scale of provisions.

The Esso Newcastle values are obtained from measured intakes, but in the scales of provisions no allowance has been made for waste which is known to have been high; this probably accounts for the very high calculated energy values in earlier centuries. Flour, sugar, milk, etc., incorporated in recipes for cooked foods, are not shown separately in the Esso Newcastle list. The table shows an increasing variety of food over the four centuries and it is clear that the earlier diets would have been scorbutic without James Lind's lemon juice. This could apply to the current statutory scale were it not a requirement under the Merchant Shipping Acts that lime juice (of doubtful potency) or concentrated orange juice must be provided in ships on voyage for more than 10 days. In each century beer has been an important source of riboflavine and the relative proportions of energy-yielding constituents - protein, fat, carbohydrate, and alcohol-appear to have been fairly constant.

The percentages of total energy derived from fat, protein, carbohydrate, and alcohol consumed by our six test subjects are shown in Fig. 1 and Table 2.

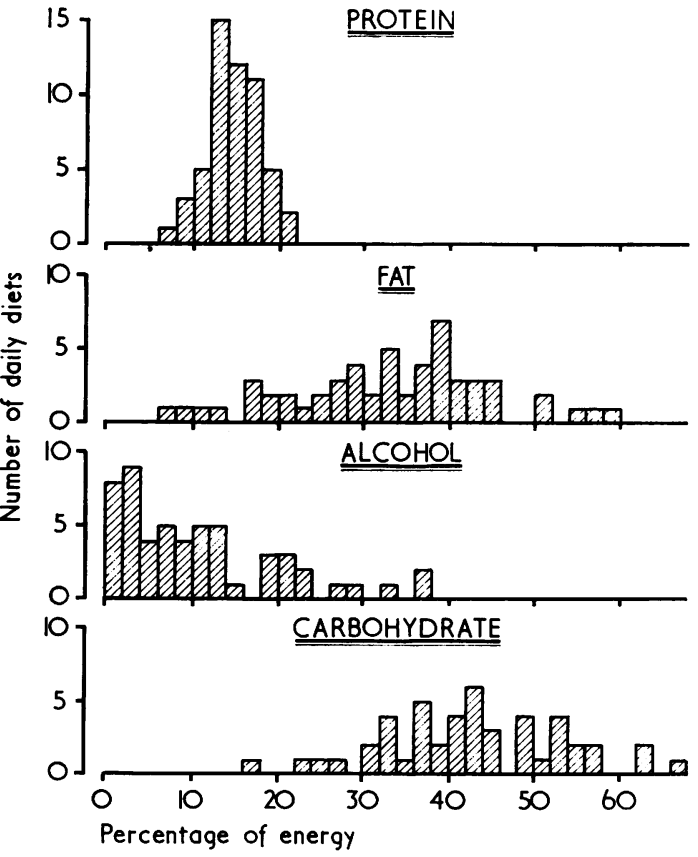

FIG. 1. Percentages of energy derived from protein, fat, alcohol, and carbohydrate in 56 daily diets from six subjects.
TABLE 2

Mean Percentages of Energy derived from Nutrients Per Day by Students and Crew SUBJECTS

\begin{tabular}{|c|c|c|c|c|}
\hline & 3 students & 3 seamen & Total & $\begin{array}{c}\text { Statistical } \\
\text { significance } \\
\text { of differences } \\
\text { between } \\
\text { students and } \\
\text { seamen }\end{array}$ \\
\hline $\begin{array}{r}\text { Protein } \\
\text { mean } \% \ldots \\
\text { S.D. . } \\
\text { S.E. . }\end{array}$ & $\begin{array}{r}15 \cdot 7 \\
2 \cdot 3 \\
0 \cdot 5\end{array}$ & $\begin{array}{r}12 \cdot 1 \\
2 \cdot 9 \\
0 \cdot 6\end{array}$ & $\begin{array}{r}13 \cdot 9 \\
3 \cdot 1 \\
0 \cdot 4\end{array}$ & $P<0.001$ \\
\hline $\begin{array}{c}\text { Fat mean } \% \\
\text { S.D. } \ldots \\
\text { S.E. } .\end{array}$ & $\begin{array}{r}38 \cdot 5 \\
7 \cdot 5 \\
1 \cdot 4\end{array}$ & $\begin{array}{r}27 \cdot 4 \\
12 \cdot 6 \\
2 \cdot 4\end{array}$ & $\begin{array}{r}33.0 \\
11.7 \\
1.6\end{array}$ & $P<0.001$ \\
\hline $\begin{array}{c}\text { Carbohydrate } \\
\text { mean } \% \\
\text { S.D. . } \\
\text { S.E. . }\end{array}$ & $\begin{array}{r}41 \cdot 1 \\
8 \cdot 6 \\
1 \cdot 6\end{array}$ & $\begin{array}{r}44 \cdot 3 \\
11 \cdot 5 \\
2 \cdot 2\end{array}$ & $\begin{array}{r}42 \cdot 7 \\
10 \cdot 2 \\
1 \cdot 4\end{array}$ & $\begin{array}{c}\text { Not } \\
\text { significant }\end{array}$ \\
\hline $\begin{array}{l}\text { Alcohol } \\
\text { mean } \% \\
\text { S.D. . } \\
\text { S.E. . }\end{array}$ & $\begin{array}{l}4 \cdot 6 \\
4 \cdot 1 \\
0 \cdot 8\end{array}$ & $\begin{array}{r}16 \cdot 1 \\
10 \cdot 1 \\
2 \cdot 0\end{array}$ & $\begin{array}{r}10 \cdot 4 \\
9 \cdot 6 \\
1.3\end{array}$ & $\mathrm{P}<0.001$ \\
\hline $\begin{array}{l}\text { No. of } \\
\text { observations }\end{array}$ & 27 & 27 & 54 & \\
\hline
\end{tabular}

There were highly significant differences between the three medical students and the crew subjects and interesting relationships between the energy-yielding constituents.

\section{Protein}

The percentage of metabolizable energy attributable to protein in the three crew subjects was $12.1 \pm$ $0.6 \%$, significantly lower than the $15.7 \pm 0.5 \%$ in the students $(P<0.001)$. The difference was partly related to alcohol consumption, for the students took less alcohol and Fig. 2 shows a negative correlation between the percentages of energy derived from alcohol and protein.

\section{Fat}

The three students took a much higher proportion of fat $(38.5 \% \pm 1.4 \%$ total energy) than the three crew subjects $(27 \cdot 4 \% \pm 2.4 \%)$, but the intake of subject $\mathbf{F}$ whose alcohol consumption was relatively moderate was similar to that of the students $(36 \cdot 1 \%)$. The inter-relationship of fat and alcohol is discussed below under 'Alcohol'.

\section{Carbohydrate}

The energy proportion contributed by carbohydrate was calculated by subtracting total percentages for 
protein, fat, and alcohol from $100 \%$. The mean intakes of students ( 41 carbohydrate Joules \%) and crew subjects (44 carbohydrate Joules $\%$ ) were not significantly different.

\section{Alcohol}

The percentage of energy attributable to alcohol taken by crew subjects was four times that taken by students. The intakes of the students and one crew subject were consistently below $12 \%$ of total energy; those of the other two crew subjects were consistently above $12 \%$ and often above $20 \%$. Only a very small proportion was taken as wine or spirits by the six subjects; practically all was taken as beer.

The variable consumption of alcohol inevitably affected the percentages of energy derived from other energy-yielding constituents, but in different degrees. Figure 1 clearly shows that protein was the least variable, but, even so, as shown above under 'Protein', protein values were slightly lowered by higher alcohol intakes. Figure 2 shows a highly significant relationship between the percentages of energy derived from alcohol and fat. There was no significant correlation between alcohol and carbohydrate. The lower concentrations of fat in the diets of the crew subjects were related to their higher consumption of alcohol.

Similar inverse relationships of alcohol intake to that of other energy-yielding constituents have been observed in French miners in the Loire by Bresard and Gombervaux (1962), who noted particularly that sugar (sucrose) consumption was lowest among those who had the highest alcohol consumption. The same appears to be true of the six Esso subjects. There was a significant negative correlation, $\mathbf{r}=$ $-0.64 \pm 0.24, P<0.01$, between total three-day energy intake of alcohol and energy intake of 'added' sugar (i.e., sugar added to beverages and sweets or candies) for the six subjects. The French miners took over 1 litre of wine per day, equivalent to more than $2.5 \mathrm{MJ}(600 \mathrm{kcal})$ alcohol; this was about twice that measured for the six subjects in

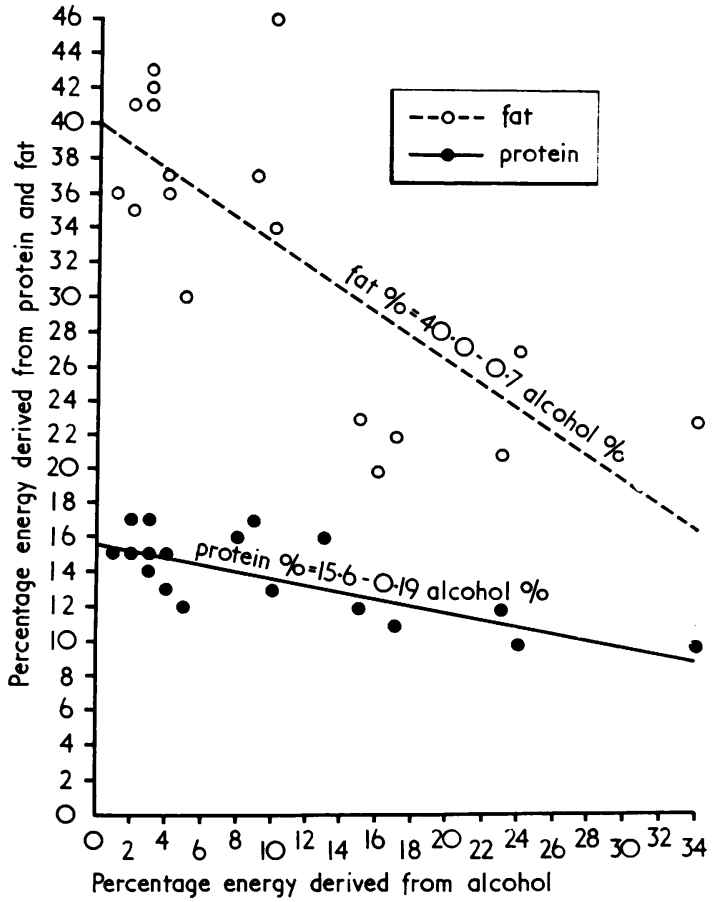

FIG. 2. Relationships of energy derived from alcohol to energy derived from fat and protein. For both regression lines $\mathrm{r}=-0.75, \mathrm{P}<0.001$.

the tanker, 1.2 MJ (277 kcal) per day equivalent to about three-and-a-half bottles $(250 \mathrm{ml})$ of beer. The French average was reached on only three occasions in 54 subject days in the Esso Newcastle and the heaviest drinkers in our subjects consumed less alcohol than the 'normal controls' in the French study. Table 3 shows a comparison between the energy-yielding nutrients taken on the ship and by French miners. Both groups show the same trend

TABLE 3

Total Energy Intakes and Proportional Contributions by Energy Nutrients in Esso Tanker SubJects AND French Miners (Bressard AND CombervauX, 1962)

\begin{tabular}{|c|c|c|c|c|c|c|}
\hline & & & \multicolumn{2}{|c|}{ Tanker subjects } & \multicolumn{2}{|c|}{ French miners } \\
\hline & & & Light drinkers & Moderate drinkers & Normal controls & Heavy drinkers \\
\hline 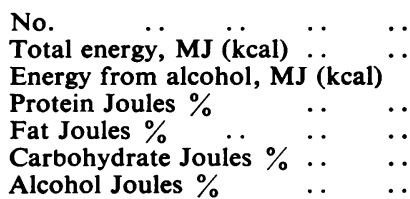 & $\begin{array}{l}\cdots \\
\cdots \\
\cdots \\
\cdots \\
\cdots\end{array}$ & $\begin{array}{l}\cdots \\
\cdots \\
\cdots \\
\cdots \\
\cdots \\
\cdots\end{array}$ & $\begin{array}{c}4 \\
12.9(3092) \\
0.6(148) \\
15 \\
38 \\
42 \\
5\end{array}$ & $\begin{array}{c}2 \\
11 \cdot 0(2639) \\
2 \cdot 2(530) \\
11 \\
24 \\
45 \\
20\end{array}$ & $\begin{array}{c}29 \\
19 \cdot 2(4549) \\
3 \cdot 1(742) \\
13 \\
32 \\
59 \\
16\end{array}$ & $\begin{array}{c}42 \\
21 \cdot 6(5164) \\
6 \cdot 7(1596) \\
11 \\
25 \\
33 \\
31\end{array}$ \\
\hline
\end{tabular}


towards decreased consumption of fats and protein with increasing intake of alcohol.

Bressard and Gombervaux (1962) and Bressard and Chabert (1963) also observed changes in the types of food consumed by heavy drinkers. There was a reduced consumption of milk and they suggested that sweet soft drinks may to some extent act as a substitute for wine. Figure 3 shows that in the six Esso Newcastle subjects there was an inverse relationship between the consumption of alcohol and that of sweet soft drinks and table sugar: most of the table sugar was added to tea and coffee. Not unexpectedly, if alcoholic drinks were not consumed, soft drinks, including sweet tea and coffee, were consumed instead. The intake of fresh milk was suggestively negatively related to alcoholic consumption in the first test, but as homogenized milk ceased to be available afterwards, it could not be drunk in the second and third tests by those who otherwise might have done so.

\section{Vitamin intakes}

Fat-soluble vitamins The intake of the fat-soluble vitamins $A$ and $D$ is shown in Table 4. Intakes were well above recommended allowances and the national average. As might be expected, the intakes of free vitamin A and vitamin D follow the pattern of fat intake. The student subjects who consumed more fat than the crew subjects also consumed more free vitamin A and vitamin D. Free vitamin A consumption by the three students was $1076 \mu \mathrm{g} \pm$ 0.145 S.E., that of the three crew subjects was $655 \pm$ $74 \mu \mathrm{g}$; similarly, consumption of vitamin $\mathrm{D}$ was, students $9.6 \pm 1.7 \mu \mathrm{g}$, and crew $5.2 \pm 0.5 \mu \mathrm{g}$.

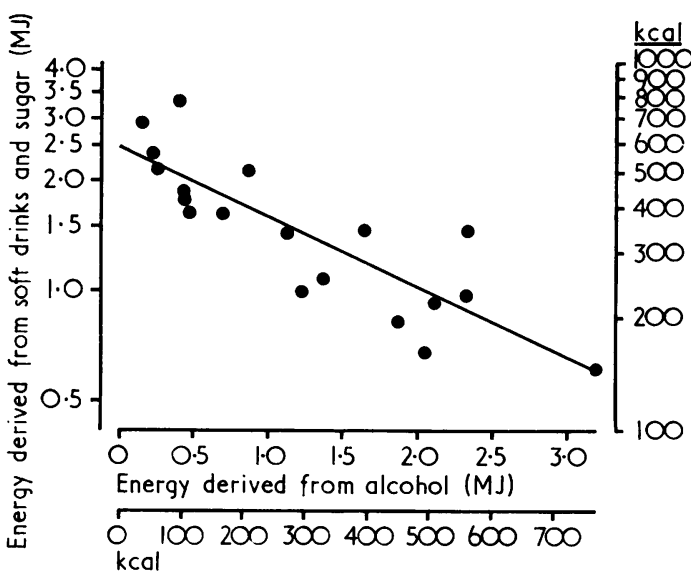

FIG. 3. Relationship of energy attributable to sweet soft drinks, table sugar, and sweets (candy) to energy derived from alcohol (y). $\log y=3 \cdot 3855-0.0034 \mathrm{KJ} . \mathrm{r}=-0.84$.

These differences are statistically highly significant. The total vitamin A consumption-including carotenes in fruits and vegetables-was the same for students and crew (2300 and $2400 \mu \mathrm{g}$ ).

The average intake of vitamin $D$ was three times greater than the intake recommended by the Department of Health and Social Security and twice as great as the average consumption in the U.K. This takes no account of the synthesis of vitamin $D$ by exposure of the skin to sunlight. The intake of fatsoluble vitamins was not affected by the duration of the voyage.

TABLE 4

INTAKES OF FAT-SOLUBLE VITAMINS

\begin{tabular}{|c|c|c|c|c|c|c|c|c|c|c|c|c|}
\hline \multirow{3}{*}{ Subject } & \multicolumn{8}{|c|}{ Vitamin $A$ ( $\mu g$ retinol equivalents) } & \multirow{2}{*}{\multicolumn{4}{|c|}{ Vitamin $D(\mu g)$}} \\
\hline & \multicolumn{4}{|c|}{$\begin{array}{l}\text { Total vitamin } A \\
\text { Test period }\end{array}$} & \multicolumn{4}{|c|}{$\begin{array}{l}\text { Free vitamin } A \\
\text { Test period }\end{array}$} & & & & \\
\hline & 1 & 2 & 3 & Total & 1 & 2 & 3 & Total & 1 & 2 & 3 & Total \\
\hline $\begin{array}{l}\mathbf{A} \\
\mathbf{B} \\
\mathbf{P} \\
\mathbf{D} \\
\mathbf{F} \\
\mathbf{G}\end{array}$ & $\begin{array}{l}2860 \\
3400 \\
3190 \\
1200 \\
1400 \\
1780\end{array}$ & $\begin{array}{l}2200 \\
1410 \\
1000 \\
3350 \\
1460 \\
3360\end{array}$ & $\begin{array}{l}1340 \\
1710 \\
1910 \\
2830 \\
1730 \\
4890\end{array}$ & $\begin{array}{l}2133 \\
2173 \\
2033 \\
2460 \\
1530 \\
3343\end{array}$ & $\begin{array}{r}1750 \\
1650 \\
1510 \\
250 \\
710 \\
480\end{array}$ & $\begin{array}{r}1010 \\
970 \\
530 \\
390 \\
1000 \\
450\end{array}$ & $\begin{array}{r}740 \\
720 \\
800 \\
740 \\
1270 \\
600\end{array}$ & $\begin{array}{r}1170 \\
1110 \\
943 \\
460 \\
993 \\
510\end{array}$ & $\begin{array}{r}17 \cdot 5 \\
12 \cdot 6 \\
6 \cdot 9 \\
3 \cdot 3 \\
5 \cdot 5 \\
4 \cdot 3\end{array}$ & $\begin{array}{r}17 \cdot 1 \\
5 \cdot 2 \\
4 \cdot 2 \\
4 \cdot 6 \\
5 \cdot 3 \\
3 \cdot 2\end{array}$ & $\begin{array}{l}7 \cdot 8 \\
6 \cdot 4 \\
8 \cdot 8 \\
8 \cdot 6 \\
5 \cdot 4 \\
6 \cdot 1\end{array}$ & $\begin{array}{r}14 \cdot 1 \\
8 \cdot 1 \\
6 \cdot 6 \\
5 \cdot 5 \\
5 \cdot 4 \\
4 \cdot 5\end{array}$ \\
\hline Mean intake of all six subjects & 2305 & 2130 & 2817 & 2420 & 1060 & 723 & 920 & 865 & $8 \cdot 3$ & $6 \cdot 6$ & $7 \cdot 2$ & $7 \cdot 4$ \\
\hline 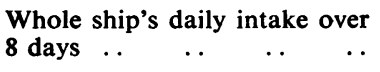 & & & & 3230 & & & & 1170 & & & & $7 \cdot 5$ \\
\hline $\begin{array}{l}\text { National Food Consumption } \\
\text { Survey } 1966 \quad \ldots \quad \ldots \\
\text { Recommended allowance }\end{array}$ & & & & $\begin{array}{r}1470 \\
750\end{array}$ & & & & & & & & $\begin{array}{l}3 \cdot 2 \\
2 \cdot 5\end{array}$ \\
\hline
\end{tabular}


Water-soluble vitamins $B$ vitamins Table 5 shows estimated intakes of thiamine, riboflavine, and niacin computed from food tables. Thiamine is not concerned in the metabolism of alcohol and this vitamin has been related to non-alcoholic energy intakes. The vitamin intakes from beer and ship's food are shown separately in Table 6 . The consumption of beer was very variable but it was a substantial source of riboflavine and niacin.

Niacin As the protein value of the diet was high, the niacin equivalent of the diet was also high. The average intake was more than twice recommended allowances of $6.6 \mathrm{mg} / 1000 \mathrm{kcal}(4 \cdot 186 \mathrm{MJ})$-in 56 subject days the intake never fell below $9 \mathrm{mg} / 1000$ kcal (4·186 MJ).

Riboflavine During the voyage the only consistent and significant change in intake in 15 'food-groups' other than changes attributable to the caprices of personal taste, was the reduction in consumption of 'liquid' milk; that is milk consumed as a drink either by itself or in a beverage such as tea. For the whole ship the consumption of $148 \mathrm{~g} / \mathrm{head} /$ day on the third and tenth days of the voyage was reduced by more than half to $44 \mathrm{~g} /$ head/day on the twenty-second to thirtieth day of the voyage. For the six subjects at successive periods milk consumption was $125 \mathrm{~g} /$ head/day on the third to fifth days of the voyage, $41 \mathrm{~g}$ on the fifteenth to seventeenth days and $18 \mathrm{~g}$ on the twenty-sixth to thirtieth days. The reduction in the consumption by the six subjects was the more remarkable in that one subject was not an habitual drinker of milk and his only recorded intake of milk
TABLE 6

B VItAMins $(m g / 1000$ KCAL $(4 \cdot 168$ MJ)/HEAD/DAY)

\begin{tabular}{|c|c|c|c|c|}
\hline \multirow{2}{*}{ Vitamin } & \multicolumn{3}{|c|}{$\begin{array}{c}\text { Esso Newcastle } \\
\text { consumption }\end{array}$} & \multirow{2}{*}{$\begin{array}{c}F A O / W H O \\
\text { recommended } \\
\text { allowances }\end{array}$} \\
\hline & Food & Beer & Total & \\
\hline $\begin{array}{l}\text { Thiamine } \\
\text { Riboflavine } \\
\text { Niacin } \\
\text { equivalent }\end{array}$ & $\begin{array}{c}0.50 \\
0.51 \\
\\
5.5 \text { niacin } \\
+ \\
\text { tryptophan } \\
=12\end{array}$ & $\begin{array}{l}0.01 \\
0 \cdot 16\end{array}$ & $\begin{array}{l}0.51 \\
0.67\end{array}$ & $\begin{array}{l}0.40 \\
0.55\end{array}$ \\
\hline
\end{tabular}

These are also the latest recommended allowances of the Department of Health and Social Security (1969).

was $20 \mathrm{~g}$ on the twenty-sixth day of the voyage. Average recorded intakes are no more than would be taken with breakfast cereals and in cups of tea or coffee, except for occasional drinks of 570 to $850 \mathrm{ml}$ taken early in the voyage by three of the subjects. The reduction in liquid milk consumption occurred when the supplies of UHTST-sterilized tetrapak milk (Long Life milk) were exhausted. The reduction in milk consumption is also shown in store issues per man per day shown in Table 7.

For the whole ship the average intake of riboflavine from food (excluding beer) was slightly less than the recommended allowance. There was a very high intake on the third to fourth days of the voyage (23 to 24 July) attributable to liver at dinner and kidney at breakfast on these days. From day 26

TABLE 5

INTAKes OF ThIAMINE, Riboflavine, AND NiACIN

\begin{tabular}{|c|c|c|c|c|c|c|c|c|c|c|}
\hline \multirow{2}{*}{ Subject } & \multicolumn{2}{|c|}{$\begin{array}{c}\text { Thiamine }(\mathrm{mg} / 1000(4 \cdot 168 \mathrm{MJ}) \text { non-alcoholic } \\
\mathrm{kcal})\end{array}$} & \multicolumn{4}{|c|}{$\begin{array}{c}\text { Riboflavine }(\mathrm{mg} / 1000 \mathrm{kcal} \\
(4 \cdot 186 \mathrm{MJ}))\end{array}$} & \multicolumn{4}{|c|}{$\begin{array}{l}\text { Niacin }(\mathrm{mg} / 1000 \mathrm{kcal} \\
\quad(4 \cdot 186 \mathrm{MJ}))\end{array}$} \\
\hline & 2 & Total & 1 & 2 & 3 & Total & 1 & 2 & 3 & Total \\
\hline $\begin{array}{l}\mathbf{A} \\
\mathbf{B} \\
\mathbf{P} \\
\mathbf{D} \\
\mathbf{F} \\
\mathbf{G}\end{array}$ & $\begin{array}{lll}0.48(0.38) & 0.50(0.44) & 0.47(0.45) \\
0.52(0.47) & 0.58(0.53) & 0.54(0.53) \\
0.49(0.44) & 0.50(0.48) & 0.54(0.54) \\
0.56(0.56) & 0.52(0.50) & 0.59(0.56) \\
0.65(0.58) & 0.48(0.37) & 0.57(0.53) \\
0.76(0.76) & 1.17(1.16) & 0.77(0.77)\end{array}$ & $\begin{array}{l}048(0.42) \\
0.51(0.48) \\
0.51(0.49) \\
0.56(0.54) \\
0.57(0.49) \\
0.90(0.90)\end{array}$ & $\begin{array}{l}0 \cdot 83 \\
1 \cdot 17 \\
0 \cdot 87 \\
0 \cdot 97 \\
0 \cdot 79 \\
1 \cdot 10\end{array}$ & $\begin{array}{l}0 \cdot 67 \\
0 \cdot 76 \\
0 \cdot 48 \\
0 \cdot 74 \\
0 \cdot 68 \\
1 \cdot 21\end{array}$ & $\begin{array}{l}0.53 \\
0.72 \\
0.65 \\
0.78 \\
0.57 \\
0.95\end{array}$ & $\begin{array}{l}0.68 \\
0 \cdot 88 \\
0 \cdot 67 \\
0 \cdot 83 \\
0.68 \\
1.09\end{array}$ & $\begin{array}{l}15 \cdot 4 \\
19 \cdot 3 \\
16 \cdot 4 \\
33 \cdot 0 \\
14 \cdot 4 \\
19 \cdot 1\end{array}$ & $\begin{array}{l}12 \cdot 0 \\
16 \cdot 8 \\
14 \cdot 6 \\
19 \cdot 1 \\
14 \cdot 4 \\
19 \cdot 5\end{array}$ & $\begin{array}{l}13 \cdot 1 \\
16 \cdot 7 \\
13 \cdot 7 \\
12 \cdot 6 \\
11 \cdot 6 \\
14 \cdot 0\end{array}$ & $\begin{array}{l}10 \cdot 1 \\
17 \cdot 9 \\
14 \cdot 9 \\
21 \cdot 6 \\
13 \cdot 5 \\
17 \cdot 5\end{array}$ \\
\hline $\begin{array}{l}\text { Mean intake of all } \\
6 \text { subjects } \\
\text { Whole ship's daily } \\
\text { intake over } 8 \text { days } \\
\text { National Food } \\
\text { Survey } 1966 \\
\text { Recommended } \\
\text { allowance }\end{array}$ & $0.58(0.53) 0.62(0.58) 0.58(0.56)$ & $\begin{array}{c}0.59(0.56) \\
0.51 \\
0.52 \\
0.40\end{array}$ & 0.95 & $0 \cdot 76$ & 0.70 & $\begin{array}{l}0.80 \\
0.67 \\
0.71 \\
0.55\end{array}$ & $19 \cdot 6$ & $16 \cdot 1$ & $13 \cdot 6$ & $\begin{array}{r}16.4 \\
14.5\end{array}$ \\
\hline
\end{tabular}

Figures in parentheses are values for thiamine with unfortified flour. 
TABLE 7

MiLK ISSUEd FROM STORE IN THE Esso Newcastle

\begin{tabular}{ll|c|c}
\hline & & $\begin{array}{c}\text { Start of voyage } \\
\text { July 1967 } \\
(\mathrm{g} / \text { man/day })\end{array}$ & $\begin{array}{c}\text { Later in voyage } \\
\text { August 1967 } \\
(\mathrm{g} / \text { man } / \text { day })\end{array}$ \\
\hline Condensed $\ldots$ & $\ldots$ & 188 & 161 \\
Evaporated.. & $\ldots$ & 13 & 44 \\
UHST Long Life & $\ldots$ & 543 & 0 \\
Cream $\quad .$. & $\ldots$ & 3 & 1 \\
\hline
\end{tabular}

(15 August) onwards, the riboflavine intake from food was below the recommended allowance, reaching its lowest point $(0.42$ to $0.44 \mathrm{mg} / 1000 \mathrm{kcal}$ $(4 \cdot 186 \mathrm{MJ}))$ on the last day of the outward voyage.

Table 5 shows a similar reduction in total riboflavine intake by the six test subjects during the three successive tests. The difference between the intake in the first test early in the voyage and the two intakes later in the voyage is statistically significant and matches the fall in milk consumption. If beer had not been available it appears from Table 6 that the intake of riboflavine would not have reached the recommended allowance. On seven different days during the last two tests, four of the subjects took no beer. Their mean daily intake of riboflavine was $0.49 \mathrm{mg} / 1000 \mathrm{kcal}(4.186 \mathrm{MJ})$.

In respect to riboflavine, beer was an adequate substitute for milk, but it is doubtful if the supply of an essential vitamin should be dependent on a beverage that may or may not be taken by everyone on board, and may or may not be available on board at any given time. Milk is a popular drink and in answer to questions on food, some of the crew stated that they would like 'long life' milk to be available for more than the first days of the voyage. It is possible that this could be done.

Thiamine In Britain there is a statutory requirement that white flour should contain at least $0.24 \mathrm{mg}$ thiamine and $1.6 \mathrm{mg}$ niacin per $100 \mathrm{~g}$. If the content of thiamine falls below this level during the milling of low extraction white flour, the statutory level is restored by adding vitamins. Flour on board the Esso Newcastle during this voyage had been obtained from Genoa and Antwerp. Samples of the Italian and Belgian flours taken off the ship were analysed with the following results.

$\begin{array}{lcc} & \text { Thiamine }(\mathrm{mg} / \mathrm{lo0} \mathrm{g}) & \text { Niacin }(\mathrm{mg} / \mathrm{lo0} \mathrm{g}) \\ \text { Italian } & 0.12 & 1 \cdot 16 \\ \text { Belgian } & 0.50 & 3.5\end{array}$

The Italian flour is typical of an unfortified white flour of low extraction. The values given for Belgian flour are well above British statutory requirements and exceed the value given for white flour in British diets by McCance and Widdowson (1960). The Belgian flour was probably fortified to a higher standard than that demanded in Britain. The values for thiamine given in Table 5 assume that typical British flour was used; the figures in parentheses show values assuming that unfortified low extraction flour was used. They are related to energy intake excluding energy from alcohol, as alcohol is not dependent upon thiamine for its metabolism.

Though it is proper to assess the diet as it was consumed, and this assessment shows that thiamine intake was adequate, it is also advisable to consider what might happen if the consumption of alcohol were to be restricted. The energy intakes of the six subjects described by Eddy et al. (1971) were not excessive and for the crew subjects intake balanced expenditure. If, therefore, the intake of alcohol were to be reduced for any reason, its energy value would have been replaced and to a considerable extent the replacement would be by sweet soft drinks and fat. It is not likely that such a replacement would have a high thiamine content, while any increase in sugar would impose an extra requirement. Relating thiamine values, using unfortified Italian flour, to total energy, the mean daily intake for the six subjects was $0.48 \mathrm{mg} / 1000 \mathrm{kcal}(4.186 \mathrm{MJ})$. This is not a deficient diet and there is no risk of deficiency in these six subjects whose mean energy intakes were $12.6 \mathrm{MJ}(3000 \mathrm{kcal})$ per day, the requirements for moderately active young men. However, with the exception of $F$, whose average intake was $14.4 \mathrm{MJ}$ $(3440 \mathrm{kcal}) /$ day and amounted to over $16.7 \mathrm{MJ}$ $(4000 \mathrm{kcal}) /$ day over one three-day test, the intakes of the six subjects were much less than the mean intake of approximately $15 \mathrm{MJ}(3600 \mathrm{kcal}) /$ day for the whole ship. Figure 4 shows that with increasing energy intake the value of thiamine per unit of energy in the diet was reduced and with intakes exceeding $14.7 \mathrm{MJ}(3500 \mathrm{kcal})$ the thiamine intake would tend to fall below the recommended intake of $0.4 \mathrm{mg} / 1000 \mathrm{kcal}(4 \cdot 186 \mathrm{MJ})$.

As requirements of thiamine are related particularly to dietary carbohydrate, Fig. 5 relates thiamine intake to energy derived from carbohydrate. If $50 \%$ of energy intake were to be derived from carbohydrate (about the proportion generally found in British diets), Fig. 5 shows that thiamine would fall below the recommended allowance $(2 \times 4 \mathrm{mg} / 1000$ carbohydrate kcal or $4.186 \mathrm{MJ})$ at 7.5 carbohydrate MJ $(1800 \mathrm{kcal})=15$ total $\mathrm{MJ}$ $(3600 \mathrm{kcal})$, i.e., the energy requirement for the whole ship. In the statutory scale of provisions shown in Table 1, 54\% of energy is derived from carbohydrates and about one quarter of the total energy provision is from bread. White unfortified bread in such a diet would result in a very low thiamine intake. 


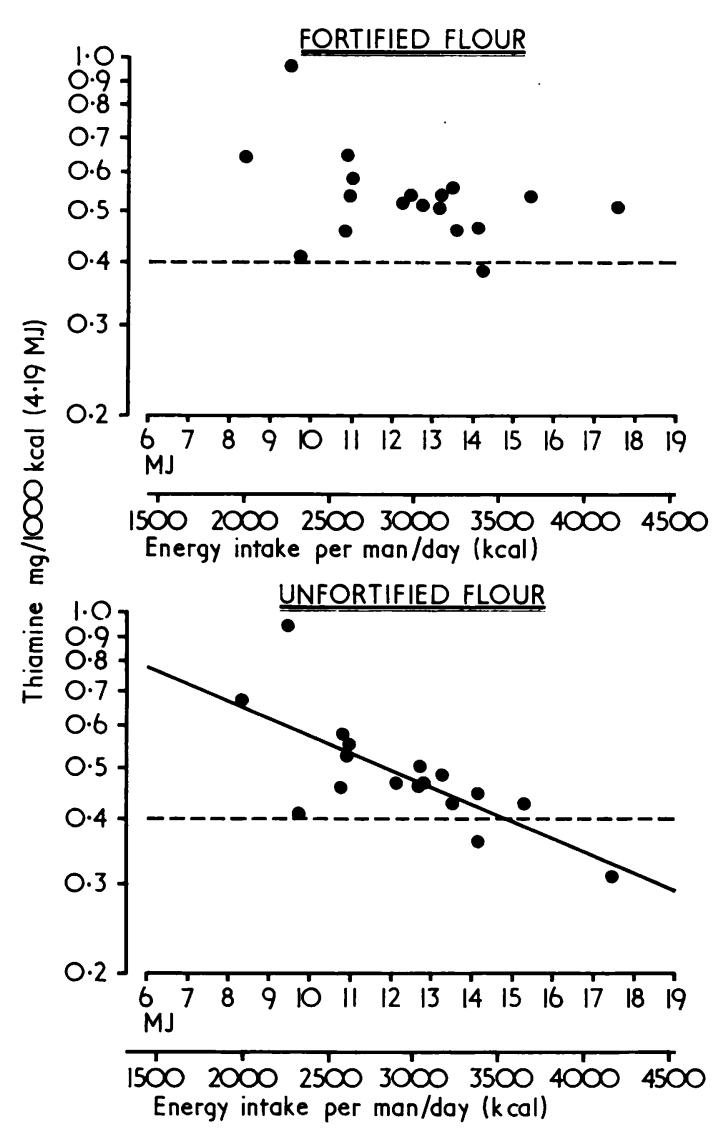

FIG. 4. Relationships of energy intake to thiamine intake. (a) Relationship with fortified flour; there is no significant correlation ( $\mathrm{r}=-0.42, \mathrm{P}>0.05)$. (b) Relationship with unfortified flour $(r=-0.73(P<0.001$. Log $y=0.7218-0.0059 \mathrm{KJ})$.

High-energy expenditures may be called for in some kinds of work at sea, and energy expenditures in such forms of seafaring as deep sea fishing or whaling may be very high. In a tanker or any other ship there may be prolonged demands for highenergy expenditures in emergencies and the crew as a whole might be called upon to be very active. Intakes of over 4000 calories/day are conceivable. Isaksson (1969), in a description of the diet in Swedish ships, gives a consumption, obtained from 24-hour dietary recall from 10 officers and $9 \mathrm{crew}$, of $14.7 \mathrm{MJ}(3500 \mathrm{kcal}) /$ day (approximately the same as the average consumption on the Esso Newcastle). The intake of several men was over $16.7 \mathrm{MJ}(4000$ $\mathrm{kcal}$ )/day and that of two men was over $20.8 \mathrm{MJ}$ $(5000 \mathrm{kcal}) /$ day.

An investigation of energy expenditures by Russian seamen in refrigerated trawlers working in

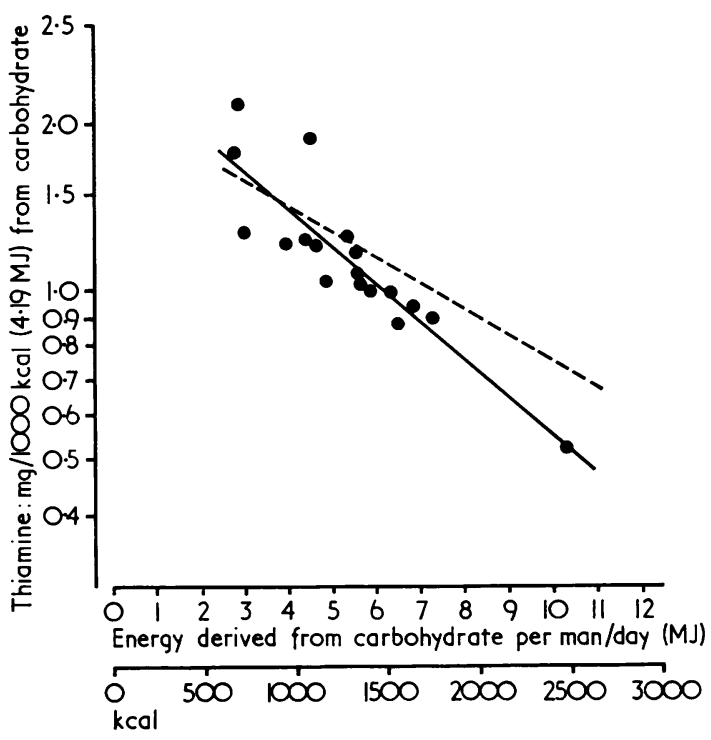

FIG. 5. Relationship of thiamine intake with energy derived from dietary carbohydrate. With fortified flour. $\log y=0.9757-0.008 \mathrm{KJ}$. $r=-0.76$. With unfortified flour there is a higher linear correlation. $r=-0.89$ $(\mathrm{P}<0.001) \log \mathrm{y}=1.0557-0.012 \mathrm{KJ}$. Plotted diets show values with unfortified flour.

the North Atlantic gave values of 17.3-30.3 MJ (4136-7238 kcal)/day (Bondarev, Zinoviev, Nepoklonov, and Enclovickaja, 1964). These values were based on indirect calorimetry using a Douglas bag. The highest expenditures were recorded in men working in refrigerated holds. A normal allowance of $\mathbf{4 0 0 0}$ calories was recommended, rising to 5500 calories when there was full work on fish handling. These calorie expenditures appear to be exceedingly high. The vitamin metabolism of the Russian seamen was also investigated and a supplement of thiamine and ascorbic acid was recommended.

Investigations which included measurements of urinary excretion of vitamin $\mathrm{C}$, thiamine, riboflavine, and niacin were also made on Russians working in fish-processing factory ships in the North Atlantic by Bondarev and his colleagues (1963), who concluded that the diet was lacking in ascorbic acid and thiamine. They recommended supplements of $5 \mathrm{mg}$ thiamine. If energy expenditures in these especially cold conditions reached these very high values, thiamine supplementation (or fortification of flour) would certainly be needed if a low extraction flour were used.

Ascorbic acid The ship's total intake of ascorbic acid during five days in the middle of the voyage is shown in Table 8. The mean intake of the whole ship 
TABLE 8

Ascorbic Acid Intake of Whole Ship during 5 days from 15 to 21 AUgust 1967

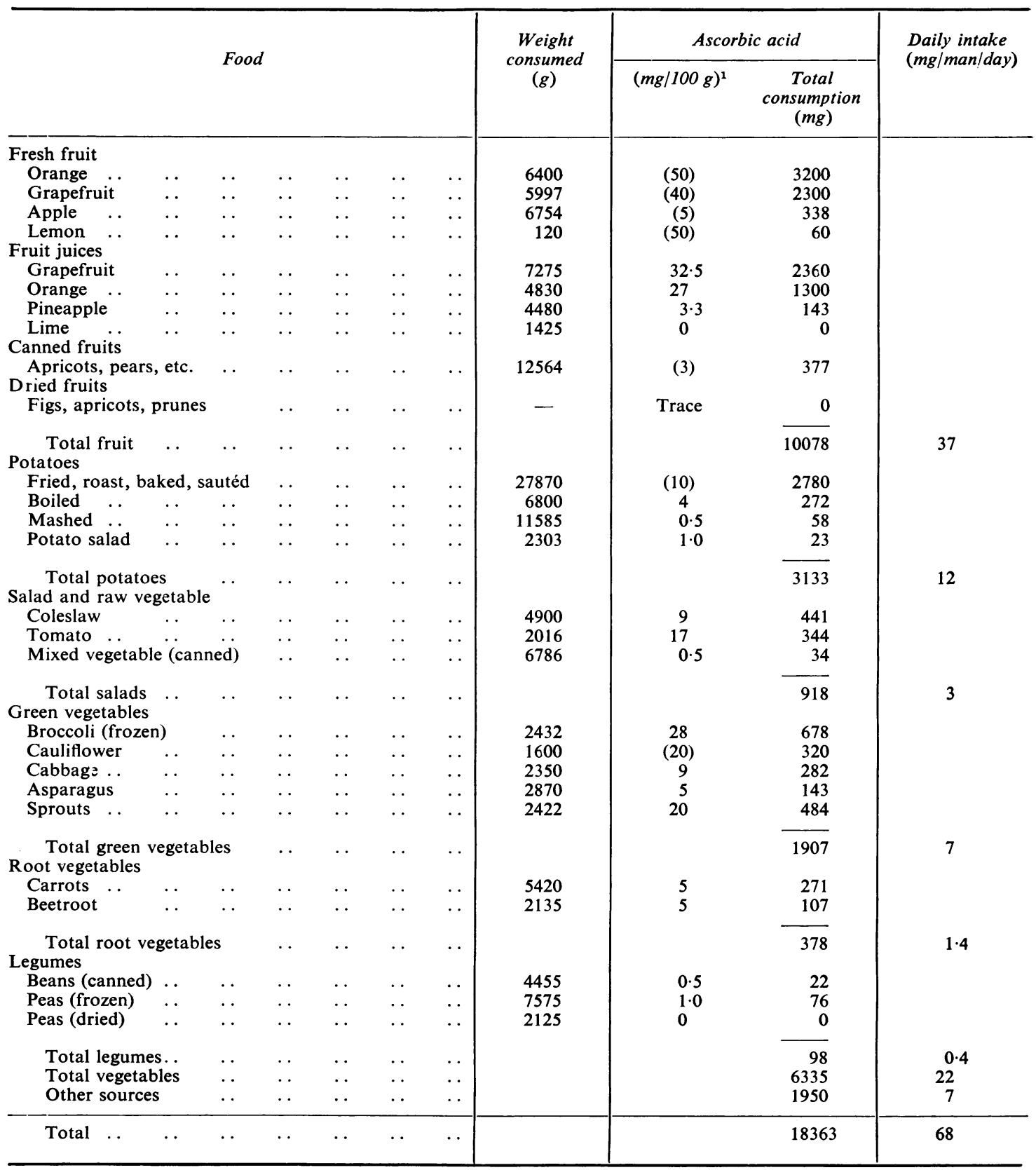

${ }^{1}$ Unbracketed figures are analysed values of reduced ascorbic acid in foods sampled as they were served at mealtimes. Bracketed figures are representative values taken from the food tables of McCance and Widdowson (1960).

for eight days of survey was $70 \mathrm{mg} / \mathrm{man} /$ day ranging from 45 to $111 \mathrm{mg}$. The intake was not affected by the length of the voyage. Analysis of samples of food taken at various stages of preparation and service, by the dichlorindophenol method shows the usual fall in values, first during cooking and finally in keeping hot before serving. For one meal, potatoes were boiled for $\mathbf{4 0}$ minutes. Cooked cabbage 
and legumes had lost 75 to $90 \%$ of their uncooked vitamin values by the time they were served.

Fruit, fruit juice or sweets or puddings containing fruit were offered on the menu four to five times daily, fresh fruit regularly once a day at the evening meal, and at breakfast there was always either fruit juice or grapefruit. The fruit juice at breakfast might be orange, grapefruit, tomato or pineapple.

Although the variety of fruit and vegetables ensured that requirements for ascorbic acid would be satisfied, the relative values of different fruits and vegetable did not appear to be appreciated. Orange and grapefruit juices contained 32.5 and $26.8 \mathrm{mg} /$ $100 \mathrm{~g}$ respectively, but pineapple juice as served on board only $3.3 \mathrm{mg} / 100 \mathrm{~g}$ and ship's lime juice, approved by the Board of Trade, as diluted and sweetened for use had a negligible quantity. The bottles of lime juice (containing $10 \%$ alcohol) were two or three years old and were used only for flavouring and colouring drinks and jellies. Apart from citrus fruits and tomatoes, the fruits served on board-bananas, apples, stewed dried fruits, and canned fruits-had a low content of ascorbic acid. Citrus fruits and fruit juices (with the exception of lime juice) made by far the greatest contribution to ascorbic acid intake, the second most important item being potatoes. The high contribution of potatoes is attributed to the high consumption of fried, roast or baked potatoes; they were often baked in their jackets. Mashed potatoes make a negligible contribution owing to destruction of the vitamin with mashing. Early in the voyage tomatoes (17 $\mathrm{mg} \%$ ascorbic acid), cucumber ( $3.5 \mathrm{mg} \%$ ), and lettuce $(0-1.0 \mathrm{mg} \%)$ were available for use in salads, but only tomatoes made any substantial contribution to intake. Coleslaw made on board from raw cabbage was the only other substantial source of the vitamin in salads.

\section{Conclusion}

Since the second world war, the national food policy in Britain has provided for the fortification of staple foods, wherever there has been any potential danger of dietary deficiencies of essential nutrients. Most people in Britain do not realize that they are protected in this way and they would not be aware of the withdrawal of this unobtrusive protection. Because of the Suez crisis, the Esso Newcastle had not been permitted to unload oil at a British port for several months and had revictualled at foreign ports. Though the risk of the occurrence of nutritional deficiency in this particular ship was negligible, the protection given by British law and practice was to some extent withdrawn and those responsible for victualling the ship were unaware that this had occurred. This unrealized withdrawal of the welfare state's protection is a possible danger to health to British seamen in ships victualling in foreign ports, particularly in ships with less variety in the diet than was provided in the Esso Newcastle.

Although there is a vast literature on the toxicology of alcohol, and the relationship of alcoholic consumption to addiction and alcoholism, comparatively few dietary studies take alcohol into consideration as a normal constituent of food or include its consumption in the sum of estimates of the energy content of diets. It is not unusual for studies to present detailed estimates of the relationships of protein, fat, carbohydrate, and vitamins, adding as an extra note that the consumption of alcohol was known to have been considerable. The National Food Survey does not mention alcohol, though its consumption in Britain accounts for an average of approximately $400 \mathrm{KJ}(100 \mathrm{kcal})$ per day for every adult, about $3 \%$ of total energy intake. As its intake is very unevenly distributed between men and women and between those who consume none and those who consume large quantities, it ought to be taken into account in any dietary assessment. It must form an important contribution to the diet of a large proportion of the world's population, and naturally fermented undistilled liquors often form an appreciable, sometimes an essential, source of riboflavine and related vitamins. Mardones (1951) has shown in experiments with rats, allowed free access to alcohol, that alcoholic consumption increased with diets low in thiamine. Presumably this is because the metabolism of alcohol, unlike other energy-yielding constituents, is not dependent on the thiamine pyrophosphate of co-carboxylase in glycolysis.

This study of seamen is of particular interest as expenditure on alcoholic liquor did not affect the availability of an abundant and varied diet, for meals are a part of a seaman's emoluments. Alcoholic consumption did not affect the consumer's expenditure on food in the way described in many other studies of deficiencies associated with alcoholism.

The statutory scale of provisions with its emphasis on split peas, dried vegetables, onions, pickles, and condiments still lives in the days of steam and sail. Conditions and exceptions allowed in applying the scale are now more important than the scale itself in ensuring that the seaman obtains a satisfactory diet, and it hinders rather than helps the catering department of a modern shipping line. It is beyond further amendment and should be scrapped. A new scale, more firmly based on modern experience in nutrition, food science and catering practice, should be drawn up.

This study would not have been possible without a great deal of help and co-operation. We should particularly like to thank the chief cook, Donald Low, and the rest of the crew in the galley who helped in the difficult work 
of weighing food in a rolling and vibrating ship. Miss Rose Delaney, of Queen Elizabeth College, assisted in the analyses of ascorbic acid.

\section{References}

Bondarev, G. I., Zinoviev, E. S., Nepoklonov, J. A., and Enclovickaja, I. S. (1963). Supplies of ascorbic acid, thiamine, rivoflavine and niacin for fish processors in trawlers of the North Atlantic Fleet. Vop. Pitan., 22, No. 5, 58-60.

- - and (1964). Energy expenditure and vitamin status of workers in large refrigerating trawlers fishing in North Atlantic waters. Vop. Pitan., 23, No. 3, 22-26.

Bresard, M., and Chabert (1963). Note sur la relation entre la consommation d'alcool et celle du sucre (Marseille, 1962). Bull. Inst. nat. Hyg. (Paris), 18, 639-649.

, and Gombervaux, C. (1962). Enquête sur la consommation des boissons auprès des mineurs du bassin de la Loire (1960). Bull. Inst. nat. Hyg. (Paris), 17, 217-265.

Collins, K. J., Eddy, T. P., Hibbs, A., Stock, A. L., and Wheeler, E. F. (1971b). Nutritional and environmental studies on an ocean-going oil tanker. 2. Heat acclimatization and nutrient balances. Brit. J. industr. Med., 28, 246-258.
,-- , Lee, D. E., and Swann, P. G. (1971a). Nutritional and environmental studies on an ocean-going oil tanker. 1. Thermal environment. Brit. J. industr. Med., 28, 237 245.

Department of Trade and Industry (1965). Inspection of Ship's Provisions under the Merchant Shipping Act. Notice No. M493 August 1965.

Drummond, J. C., and Wilbraham, A., revised by D. Hollingsworth (1958). Appendix A, pp. 465-7. The Englishman's Food. Cape, London.

Eddy, T. P., Stock, A. L., and Wheeler, E. F. (1971). Nutritional and environmental studies on an ocean-going tanker. 3. Energy balances and physique. Brit. J. industr. Med., 28,330.

Isaksson, B. (1969). Food consumption in merchant ships. Personal communication of paper published in J. Swedish Merchant Navy Stewards.

McCance, R. A., and Widdowson, E. M. (1960). The Composition of Foods. Spec. Rep. Ser. med. Res. Coun. (Lond.), No. 297.

Mardones, R. J. (1951). On the relationship between deficiency of B vitamins and alcohol intake in rats. Quart. J. Stud. Alcohol., 12, 563-575.

Received for publication March 27, 1971. 